\title{
高精度自由曲面形状測定装置の開発*
}

\author{
根 岸 真 人** \\ Development of a high precision free-form measurement machine
}

\section{Mahito NEGISHI}

\begin{abstract}
This paper describes a high-precision free-form measurement machine named "A-Ruler." It will be used to measure the shape of freely curved surfaces with a precision of $5 \mathrm{nmRMS}$ at a measurement volume of $350 \times 80 \times 50 \mathrm{~mm}^{3}$. A contact-type probe guided by a pair of parallel springs is employed for its capacity to easily measure oblique surfaces. The probe's five motion errors are measured and compensated for using six laser interferometers and three mirrors arranged perpendicularly to each other. This is the core structure of the device, and it ensures accuracy of measurement. On the other hand, other portions such as $\mathrm{XYZ}$-slides are made with rather ordinary components. Studies on margin of error indicate that the measurement of a spherical surface is influenced by almost all types of errors. Therefore, the performance of A-Ruler can be assessed by measuring a spherical surface. A concave sphere work-piece made of Zerodur ${ }^{\mathrm{TM}}$ was prepared for this purpose. Its curvature radius is $104.508 \mathrm{~mm}$, the evaluation area is $\phi 120 \mathrm{~mm}$ and the maximum angle of obliqueness is 35 degrees. The repeatability, or the difference between two consecutive measurements, is $3.8 \mathrm{nmRMS}$. The error of the probe's sphericity is found to be sufficiently small compared to this repeatability. Precision is assessed by comparison with an interferometer. The difference between A-Ruler and the interferometer is $3.5 \mathrm{nmRMS}$ per $\phi 120 \mathrm{~mm}$ area.
\end{abstract}

Key words: coordinate measurement machine, free form, aspherical optics, contact probe, parallel spring, laser interferometer

\section{1. 緒言}

デジタルカメラやレーザープリンタ，HMD(Head Mounted Display)など光を利用した情報機器の急速な性能向上を高性能 光学素子が支えている．特に光学素子の形状を非球面，あるい は自由曲面とすることで，設計段階での著しい性能向上が可能 となり，新しい製品コンセプトにつながっている。これら光学 素子は単品ごとに製作するか，型を製作し，プラスチックやガ ラス成形によって大量生産する。いずれの場合でも球面や平面 の場合と異なり，形状を創成する加工原理が存在しないため, 測定にもとつ゚いて形状を修正する必要がある。この形状修正サ イクルの採用により，自由曲面形状においても加工精度を測定 精度にまで，高めることが原理的には可能である，特に，研磨 のように除去量を小さくできる加工方法との組み合わせにおい ては測定䜋差が光学素子の精度を大きく左右する。これまで大 型非球面光学素子を対象に CSSP (Canon Super Smooth Polisher) と呼ぶオンマシン形状測定装置を開発し, 繰り返し性 $9 \mathrm{nmRMS}$ が得られることを確認してきた !。本研究では前述したニーズ に応えるため, 自由曲面を再現性 $5 \mathrm{nmRMS}$, 精度 $5 \mathrm{nmRMS}$ 測定することを目標に小型の形状測定装置を開発し ${ }^{2)}$ ，ナノメ ートルオーダーの測定が可能であることを示す.

\section{2. 装置 構 成}

\section{$2-1$ 概要}

干涉計を用いた方法は，被測定物全面を同時に，しかも高精 度に測定できるため広く使用されており，その測定再現性はす でに50 pm に達している ${ }^{3)}$. しかしミリメートルオーダーの大

*原稿受付 平成13年 2 月 19 日

** 正会 員 キヤノン (株) (東京都大田区下丸子 $3-30-2$ )

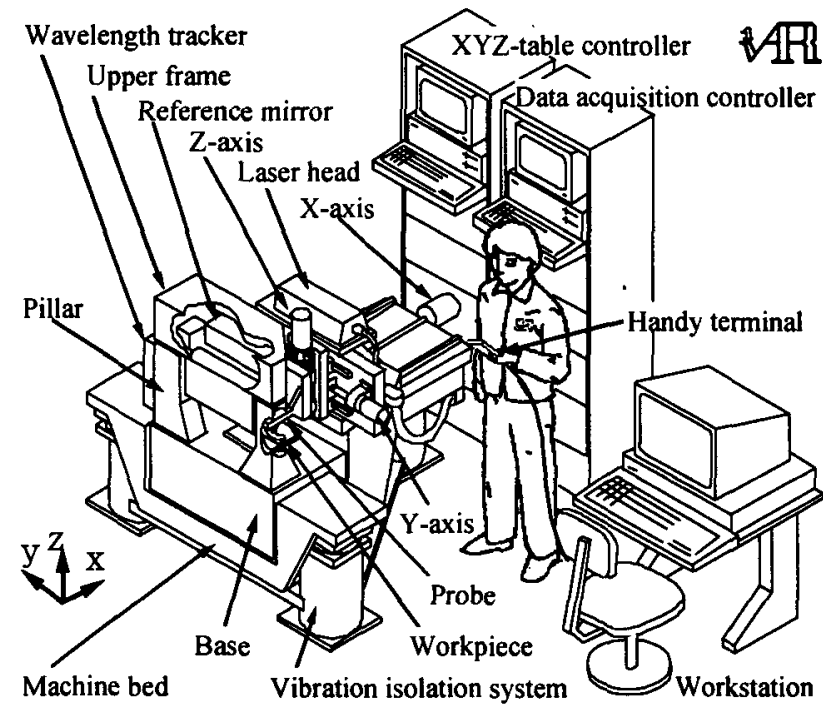

Fig.1 A-Ruler, a high-precision coordinate measurement machine

きな非球面量に対して参照波面を作ることは困難であり，前述 したニーズに応えることは不可能と思われる，そこでプローブ を走査させ，1点づつ測定する測定方法を採用した。このよう な装置 ${ }^{477}$ は, 形状に追従するプローブ部分とプロープの位置を 測定する座標測定部分からなる。プローブは簡便に被測定物の 傾斜角度に対応できる接触式を採用し，座標測定は 3 面の位置 基準に対する距離を測定して位置, 姿勢誤差を補傥する構成と した. 図 1 にA-Ruler と呼ぶ装置の外観を示す. 測定領域は 350 x $80 \times 50 \mathrm{~mm}$ とし，恒温クリーンチャンバーに設置する。この

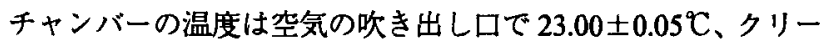
ンクラスは 100 である。次に主な棈成要素であるプロープと座 標測定について述べる。 


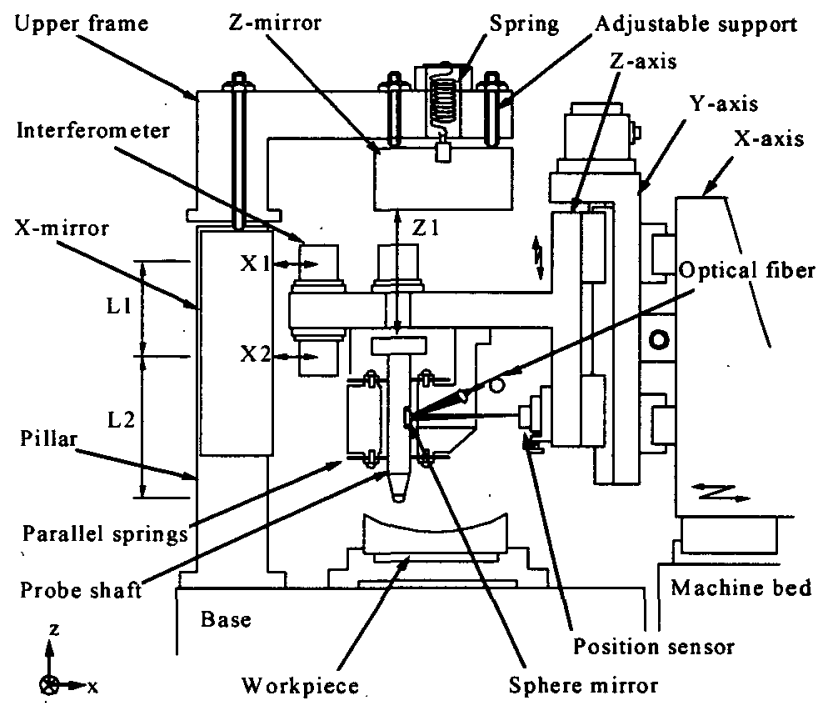

Fig. 2 Cross sectional view of A-Ruler

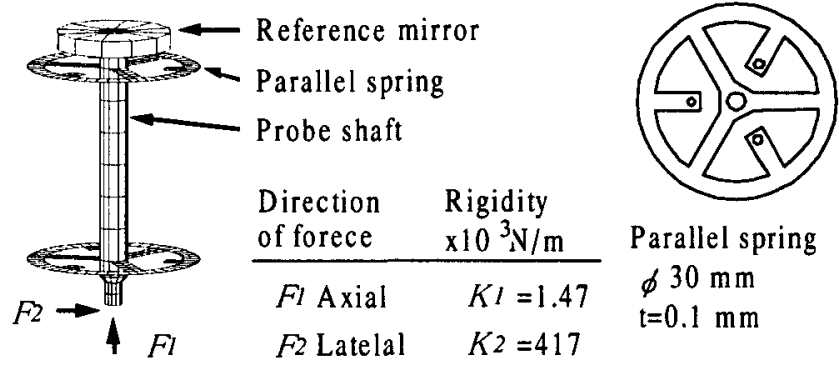

Fig. 3 Contact probe comprising parallel springs

Table 1 Error factors

\begin{tabular}{lllccc} 
Error factors & & & \multicolumn{3}{c}{ Measurem ent test } \\
\hline Item & & A main cause & Point & Flat & Sphere \\
\hline Probe & Contact & Contamination & & $\checkmark$ & $\checkmark$ \\
& Tip sphere & Sphericity & & & $\checkmark$ \\
& Probe shaft & Deformation & & & $\checkmark$ \\
\hline Coordinate & Data sampling & Degitizing & $\checkmark$ & $\checkmark$ & $\checkmark$ \\
measurem ent & Interferometer & A ir turbulence & $\checkmark$ & $\checkmark$ & $\checkmark$ \\
& Mirror & Deformation & & $\checkmark$ & $\checkmark$ \\
& Frame & Mirror alignment & & & $\checkmark$ \\
& Scanning & Vibration & & $\checkmark$ & $\checkmark$ \\
\hline \multirow{2}{*}{ Workpiece } & Holder & Gravity & & $\checkmark$ & $\checkmark$ \\
& Sample & Temperature & $\checkmark$ & $\checkmark$ & $\checkmark$
\end{tabular}

\section{$2-2$ 接触式プローブの構成}

图 2 は装置の断面図である. 形状測定にゼロ位法を採用した。 つまり Z 軸を用いてプローブの変位を一定に制御しながら X， Y，Z座標を測定する．従ってプローブの非線形性が問題なく なるほか，ストロークを狭くすることができ，姿勢変動も少な くなるため精度向上が期待できる，今回，ストロークは狭いが 容易に高い精度が得られる平行板ばねを採用した，板ばねのた わみを一定に制御することによって一定の押し付け力を得る構 成である.板ばねのたわみは光てこを用いた変位計で測定する. 光ファイバから出射するレーザー光をレンズでコリメートし， プローブに固定した凸球面で反射，ポジションセンサに集光さ せる.するとプローブ変位は光てこで拡大され，焦点位置が動 く. 䄪 40 倍の拡大率を採用したが，この構成でサブミクロン の分解能が容易に得られる．また，この変位計の誤差は針圧の
変動となるが, プローブの位置はレーザー測長器で測定してい るので精度に直接は影響しない.プローブの先端には $\phi 0.8 〜$ $2 \mathrm{~mm}$ の鋼球を取り付ける. 現在グレード 2 の鋼球が使用可能で, この場合, 真球度の規格は50 nmである. 実際の真球度につい ては後述する実験により影響を確認する，針圧については光学 材料の中でも脆性材料である $\mathrm{CaF}_{2}$ 結晶面に傷をつけないこと を実験的に確認した針圧 3１0 mNを操用した”. 板ばねの設計 例と FEM 計算結果を図 3 に示す。後述するように縦横の剛性比 が大きい方が有利であるので板ばねの間隔は約 $60 \mathrm{~mm}$ と長くと った.また, 板ばねの形を 3 回対称とし，方位による横剛性の 変化が少ない構成とした。 そして, 被測定物との衝突を避ける ため板ばねの支持点を内側に配置している，また，温度変化の 影哑を軽減するためプローブシャフトは線熱膨張係数 $0.5 \times 10^{-6}$ $\mathrm{K}^{-1}$ のスーパーインバーで, プローブ上の参照ミラーは合成石英 ガラスで製作した.

\section{2-3 座標測定方法}

図1，2に示したように，低熱膨張ガラス Zerodur ${ }^{\mathrm{TM}}$ で製作 した 3 面の参照ミラーを互いに直行して配置し, 分解能 $1.25 \mathrm{~nm}$ のレーザー測長器でミラーに対するプローブの位置を測定する. この場合, 測定の基準は被測定物を固定するべースとそれに柱 を立てて固定した上部フレーム, 参照ミラーからなる箱状の構 造物となる。こ机と Z 軸は測定精度を左右するので線熱膨張係 数 $0.5 \times 10^{-6} \mathrm{~K}^{-1}$ の低熱膨張鋳鉄で製作する. 一方，測定基準を支 えるベッド，およびプローブ走査に用いるXY軸は測定精度に 直接影響しないので通常の構成要素で十分である.ころがり式 のガイドとボールネジを採用した。このため例えばX軸の分解 能は約 $0.2 \mu \mathrm{m}$, さらに約 $60 \mu \mathrm{rad}$ の姿勢誤差が生じる.そこ で, レーザー測長器で複数の位置を测定し,この䛊差を補償す る. その方法は, 図 2 において, 測長軸 $x_{1}, x_{2}$ および先端球 中心の上下方向の間隔を $L_{1}, L_{2}$ とすると次式でプローブ先端 球中心の XY座標を計算すれでよい。

$$
\begin{aligned}
& x=x_{1}+\left(x_{2}-x_{1}\right)\left(L_{1}+L_{2}\right) / L_{1} \\
& y=y_{1}+\left(y_{2}-y_{1}\right)\left(L_{1}+L_{2}\right) / L_{1}
\end{aligned}
$$

この方法でX, Y方向の位置決め誤差とX, Y 軸まわりの 回転誤差を補償できる。また, $Z$ 座標は $Z$ ミラーとプローブ 間の距離を干涉計で直接測定する。

\section{3-1 誤差要因}

\section{3。测 定 誤 差}

装置構成に基づいた测定ループを考え，誤差要因を表 1 の ように分類する，第 1 の項目は接触式プローブに関し，さら に, 被測定物と先端球間の接触部分，先端球，それを支える シャフト部分に分ける．第2の項目は座標測定に関し，サン プリング, レーザー測長器 (干涉計), 参照ミラー, フレーム, そして走查軸に分類する. 最後の項目は被測定物の変形であ る.この誤差要因の影響を調べるために 3 種類の測定, 点測 定, 平面の測定そして球面の測定を行った，点測定は座標の 測定再現性, 特に温度ドリフトやレーザー測長器の空気ゆら き，振動などに影響される．平面の測定は $Z$ 方向の座標測定 精度, 走查に関する誤差要因が加わる. そして球面の測定は 全部の項目について影㸷を受ける.つまり，球面を測定する ことで，本測定装置の性能を検查することができる。

次に第 1 ，第 2 の項目について述べる. 


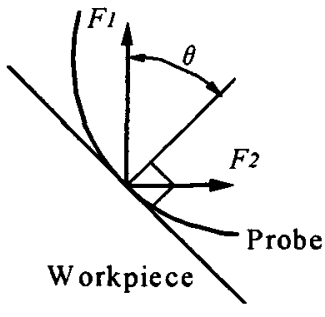

(a)

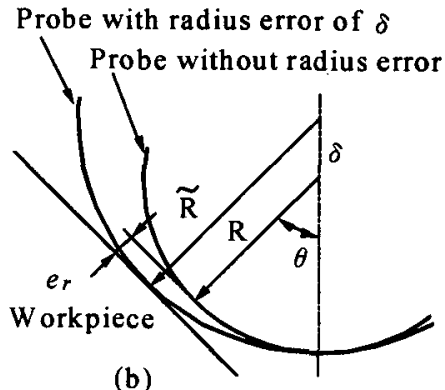

(b)
Fig. 4 Influence of probe's (a) lateral deformation and (b) radius error

\section{3-2 接触式プローブに関する測定誴差と補償方法}

この項目の中で最も影響が大きいのは被測定物表面のよごれ であり，数十 $\mathrm{nm}$ から数十 $\mu \mathrm{m}$ の測定誤差を生じる. 被測定物 の洗浄と, ソフトウエアによる異常な測定点の抽出がポイント となる.プローブシャフトの変形については図 3 の FEM モデル (縦剛性 $K_{1}=1.47 \mathrm{~N} / \mu \mathrm{m}$, 横剛性 $K_{2}=417 \mathrm{~N} / \mu \mathrm{m}$ ) から検討する. 图 4 (a)はプローブと $\theta$ 傾斜した被測定面の間に作用する力を 示している．前述したように ARuler では垂直方向の力 $F_{1}$ が一 定になるように制御される．摩擦力を無視するとプロープにか かる横方向の力 $F_{2}$ は $F_{1} \tan \theta$ となり, 法線方向の測定誤差 $e_{p}$ は次式のようにかける。

$$
e_{p}=\frac{F_{1}}{K_{2}} \tan \theta \sin \theta
$$

従って傾斜角 $\theta$ のほほ 2 乗に比例した測定誤差が予想される。 例えば傾斜角 45 度，針圧 $10 \mathrm{mN}$ とすると $17 \mathrm{~nm}$ の誤差となる。

また，図 4 (b)に先端球半径䛊差 $\delta$ 影翌を示す. 傾斜角 $\theta$ の 表面を測定する場合，測定䛊差 $e_{r}$ は次式となる.

$$
e_{r}=\delta(1-\cos \theta)
$$

さきほどの $e_{p}$ と同様,傾斜角のほほ 2 乗に比例する.そこで, 先端球半径を補正し，これらの誤差を補償することができる. 具体的な方法は曲率半径が既知の形状を測定し, その結果から 先端球半径の補正量 $\delta$ を計算する。

また別の方法は，プローブの剛性から補正量 るを推定するこ とである. 傾斜角が 0 と $\theta_{0}$ の時に補正誤差 $e_{c}=e_{p}-e_{r}$ を ゼロと仮定することにより，

$$
\delta=\frac{F_{1} \tan \theta_{0} \sin \theta_{0}}{K_{2}\left(1-\cos \theta_{0}\right)}
$$

\section{この時の補正誤差は}

$$
e_{c}=e_{p}-e_{r}=\frac{F_{1}(\cos \theta-1)\left(\cos \theta-\cos \theta_{0}\right)}{K_{1} \cos \theta \cos \theta_{0}}
$$

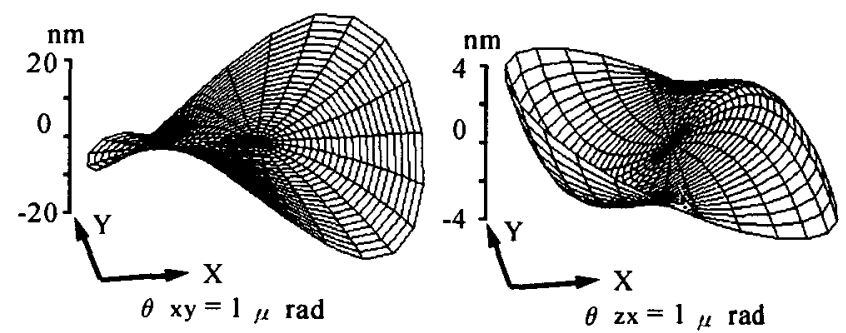

Fig.5 Error caused by orthogonal errors

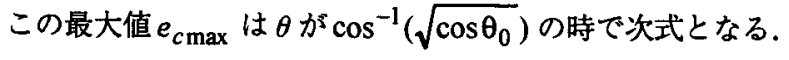

$$
e_{c \max }=\frac{F_{1}}{K_{2}}\left(\frac{2}{\sqrt{\cos \theta_{0}}}-\frac{1}{\cos \theta_{0}}-1\right)
$$

例えば図 $3 に$ 示したプローブで $\theta_{0}$ を 45 度とすると，さきほ ど計算したプローブシャフトの変形による測定誤差 $e_{p=17} \mathrm{~nm}$ に対し、これを補正した時の残差 $e_{c \max }$ は $0.86 \mathrm{~nm}$ となる。

\section{3-3 座標測定に関する測定誤差と捕償方法}

上側のフレームに懸架されている基準ミラーは重力により変 形する. 特に上下の Z座標を測定するミラーについて $12.7 \mathrm{~nm}$ の変形が予想された．そこで，多点でこれを支持し，自重変形 を2.7nmに押さえる2)

また, XYZ座標軸間の直角度は, XYZミラーの取り付け 諤差にかかっているので大きな測定誤差となる．例えば直角度 $1 \mu \mathrm{rad}$ に組み立てるのは難しい課題である. そこで, 球面原器 を測定し，そ礼を真球と仮定して直角度を推定する。いわゆる ボールバーテストと同じ原理である，座標軸間の直角度を $\theta_{x y}$, $\theta_{z x}, \theta_{z y}$ ，誤差を含んだ座標を $\tilde{x} ， \tilde{y} ， \tilde{z}$ と表す。また，測 定結果には球面原器の取り付け位置誤差が含まれるのでこれを $x_{0}, y_{0}, z_{0}$ とし，これらのパラメータがすべて微少だとする と誤差を含んだ座標は次のように定義できる。

$$
\left\{\begin{array}{l}
\tilde{x} \\
\tilde{y} \\
\tilde{z}
\end{array}\right\}=\left[\begin{array}{ccc}
1 & -\theta_{x y} & \theta_{z x} \\
0 & 1 & -\theta_{z y} \\
0 & 0 & 1
\end{array}\right]\left\{\begin{array}{l}
x \\
y \\
z
\end{array}\right\}+\left\{\begin{array}{l}
x_{0} \\
y_{0} \\
z_{0}
\end{array}\right\}
$$

凹球面原器 $z=R-\sqrt{R^{2}-x^{2}-y^{2}}$ を測定した場合, 測定される 形状誤差,すなわち法楾方向の偏差 $e(x, y)$ は,

$$
\begin{aligned}
& e(x, y)=\left(\left\{\begin{array}{l}
\tilde{x} \\
\tilde{y} \\
\tilde{z}
\end{array}\right\}-\left\{\begin{array}{l}
x \\
y \\
z
\end{array}\right)\right) \cdot\left\{\begin{array}{c}
-x \\
-y \\
R-z
\end{array}\right\} / R \\
& =\left(\theta_{x y} x y-\left(\theta_{z x} z+x_{0}\right) x+\left(\theta_{z y} z-y_{0}\right) y+z_{0}(R-z)\right) / R
\end{aligned}
$$

次に被測定物の取り付け位置誤差を最小 2 乗法を用いて推定 計算する.測定範囲を半径 $p$ の円領域とし，次の積分を考える.

$$
Q=\int_{0}^{2 \pi} \int_{0}^{p} e(r \cos \phi, r \sin \phi)^{2} r d r d \phi
$$

これが最小になるように取り付け位置誤差を計算すると，

$$
\begin{aligned}
& x_{0}=\theta_{z x}\left(8 R^{5}-15 p^{4} R-2 R_{0}\left(2 R^{2}-2 p^{2}\right)\left(2 R^{2}+3 p^{2}\right)\right) / 15 p^{3} \\
& y_{0}=-\theta_{z y}\left(8 R^{5}-15 p^{4} R-2 R_{0}\left(2 R^{2}-2 p^{2}\right)\left(2 R^{2}+3 p^{2}\right)\right) / 15 p^{3} \\
& z_{0}=0
\end{aligned}
$$

\section{ここで $R_{0}=\sqrt{R^{2}-p^{2}}$ ．これを式 7 に代入し測定誤差}

を計算することができる．誤差の評価は PV(Peak to Valley)值や 次式で計算される RMS(Root Mean Square)值を用いる.

$$
E=\sqrt{Q / \pi p^{2}}
$$




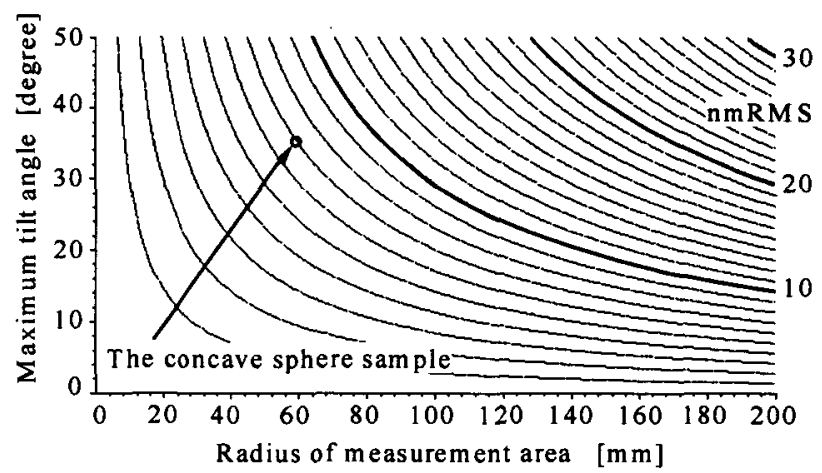

Fig. 6 Measurement error caused by $\theta$ xy

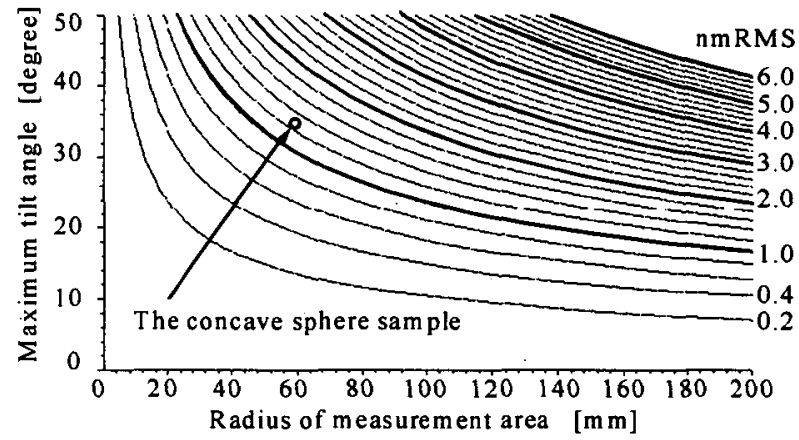

Fig. 7 Measurement error caused by $\theta \mathrm{zx}$

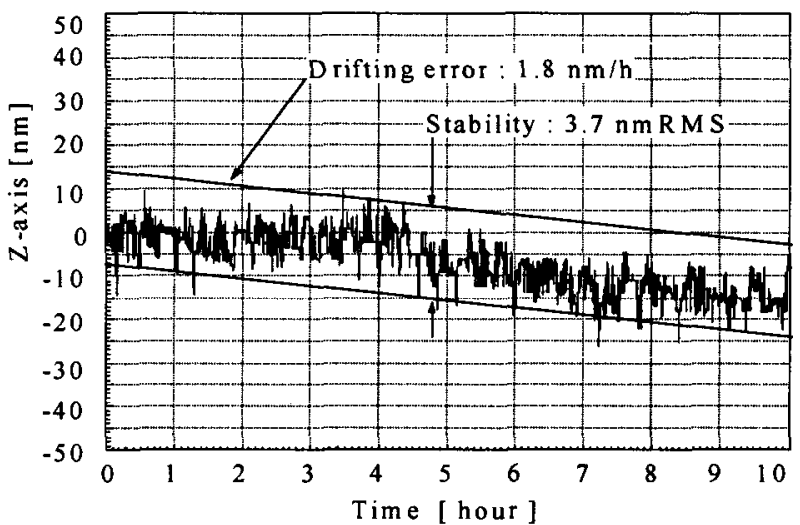

Fig. 8 Point measurement test (Stabilitv of Z-axis)

つまり10式は上記 RMS 值を最小にする計算だった。例え ば最大傾斜 35 度, 領域 $\phi 120 \mathrm{~mm}$ で球面原器を測定する場合を 考える.これは後述する測定評価に用いた球面サンプルである。 直角度誤差 $\theta_{x y}$ を $1 \mu \mathrm{rad}$ とし, 式 8 から測定誤差を計算すると $34.4 \mathrm{nmPV}, 7.0 \mathrm{nmRMS}$ となる. $\theta_{z x}$ の場合は $7.6 \mathrm{nmPV}, 1.3$ nmRMS となる.このようにして計算した $\phi 120 \mathrm{~mm}$ 測定領域に おける測定誤差の形状を图 5 に示す。このように同じ角度誤差 でも $\theta_{x y}$ の影譬が $\theta_{z x}$ よりも 4 倍以上大きい.

球面の測定において直角度誤差の影響は測定領域の大きさと 最大傾斜角によって変わる.そこで $1 \mu \mathrm{rad} の$ 直角度誤差を仮定 し, 測定誤差の RMS 值を様々な被測定物の形状に対して計算 すると图6，図7が得られる。上図には先ほどの球面サンプル も示す。この球面を用いて補正すれば, 球面サンプルのカーブ よりも左下にある被測定物については直角度誤差の影餢が小さ いと言える.また，全般的に $\theta_{x y}$ は $\theta_{z x}$ よりも影響が大きい.

今回は 4-3 節で説明する真球度 $18 \mathrm{nmPV} の$ 球面を用いたが, この誤差の影響については今後検討する必要がある.

\section{4. 性 能 評 価}

\section{4-1 1 点の測定}

表 1 に示した誤差要因の大きさを見積もるため前述したよう

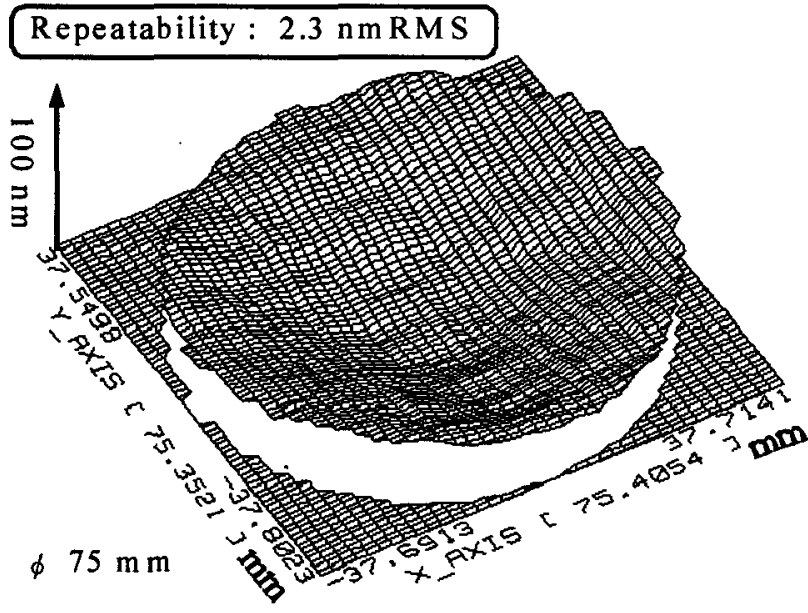

Fig. 9 Measurement of a flat surface

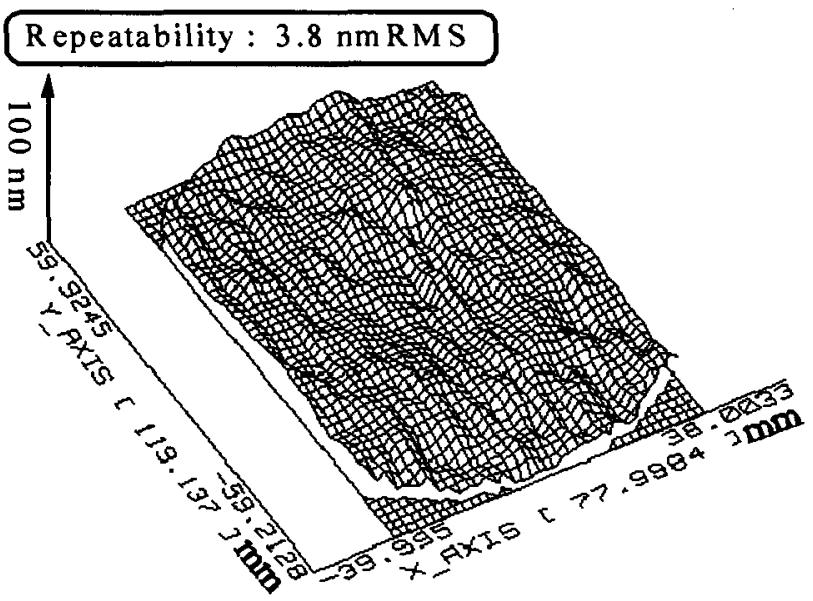

Fig. 10 Measurement of a sphere surface

に3種類の測定を行った。まず，点測定はゼロデュアで製作し た平面原器にプローブを接触させ，Z座標の変化を測定する. 図 2 に示した構造から，Z座標の変化は精度基準であるべース などの構造物の温度ドリフトやレーザー測長器の空気ゆらぎ， 振動などに影響され，本測定装置の座標測定誤差を表すと考え られる。

10 時間測定した結果を图 8 に示す．ランダムなばらつきが $3.7 \mathrm{nmRMS}$ ある。これを低減するために，形状測定結果に空間 的なローパスフィルタをかける，すると複数の測定点を平均す ることになるので，ランダムな座標測定䛊差の影響を低減する ことができる。この時，測定する空間周波数に対して十分測定 点数が多くなるように注意が必要である。また，この方法では 対処できないドリフト誤差は 1 時間あたり $1.8 \mathrm{~nm}$ であった. 実 際の測定は 20 分程度を想定しているので目標の測定精度に対 し十分小さいと言える.

\section{4-2 平面の測定}

图 9 は合成石英ガラスで製作した $\phi 100 \mathrm{~mm}$ ，厚さ $10 \mathrm{~mm} の$ 平面を測定した結果である。先端球は $\phi 2 \mathrm{~mm}$ の鋼球，針圧 7.9 $\mathrm{mN}$, 走査速度 $9 \mathrm{~mm} / \mathrm{s}$ とした. 1 回の測定時間は約 9 分である. 被測定物の取付け䛊差である Z 方向と傾斜成分は測定結果から 除去する. 先ほどの1点の測定に対し，プローブ走査に伴う誤 差, Zミラー形状誤差などの影響が増えるが，前述したように ランダムな誤差を低減するためにローパスフィルタを用いる. 走査ラインのピッチが $2 \mathrm{~mm}$ なのでこのフィルタのカットオフ 
周期を $4 \mathrm{~mm}$ とした。

繰り返し性を評価するのに，2 回の測定結果の差を用いた。 この評価値 $\left(E_{r}\right.$ とする) は評価領域を $A$, 第 $\mathrm{n}$ 回の測定を $f_{n}(x, y), 2$ 回の差を $d(x, y)=f_{1}(x, y)-f_{2}(x, y)$, 評価領域 を $\mathrm{A}$ とすると次式で定義される。

$$
E_{r}=\left(\iint_{A} d(x, y)^{2} d x d y / A-\left(\iint_{A} d(x, y) d x d y / A\right)^{2}\right)^{1 / 2}
$$

図 9 に示した $\phi 75 \mathrm{~mm}$ 平面測定における繰り返し性を 2 回の 測定結果の差 $E_{r}$ で評価すると $2.3 \mathrm{nmRMS}$ であった。

また，測定結果が多数ある場合には平均形状からの差のばら つきで評価するほうが便利である．この評価值 $E_{s}$ は,

$E_{s}=\left(\frac{1}{A} \iint_{A}\left(\sum_{n=1}^{N} f_{n}(x, y)^{2} / N-\left(\sum_{n=1}^{N} f_{n}(x, y) / N\right)^{2}\right) d x d y\right)^{1 / 2}$

偶発的な測定誤差が位置や測定回数によらず一定とすると， これら 2 つの評価値の関係は $E_{r}=\sqrt{2} E_{s}$ となる.

\section{4-3 球面の測定}

図 10 はゼロデュアで製作した曲率半径約 $104.508 \mathrm{~mm}$ の凹 球面原器の測定結果である. 評価領域は $\phi 120 \mathrm{~mm}$ で最大傾斜角 35 度である.ただし, 本装置の最大測定領域の制約からX方向 については $80 \mathrm{~mm}$ に制限されている. 先端球は $\phi 2 \mathrm{~mm}$ の鋼球, 針圧 $9.8 \mathrm{mN}$, 走查速度 $4 \mathrm{~mm} / \mathrm{s}$ で測定した. 1 回の測定時間は 約 20 分である.

被測定物の取り付け䛊差である位置と曲率半径は最小 2 乗法 で推定し測定結果から除去する，表 1 で説明したように本測定 装置の䛊差要因を全部含むので，この球面の測定が本装置の綕 合的な性能評価になると考えられる。

評価領域において繰り返し性 $E_{r}=3.8 \mathrm{nmRMS}$ が得られた。 た, 式 13 による評価値は $E_{s}=2.5 \mathrm{nmRMS}$ となる。

\section{4-4 先端球の影翠}

图 11 はさきほどの凹球面原器の同じ中央断面において, 先 端球を毎回変えながら 10 回測定した結果である。用いた球は グレード 2 の $\phi 2 \mathrm{~mm}$ 鋼球, 針圧 $9.8 \mathrm{mN}$, 走查速度は $4 \mathrm{~mm} / \mathrm{s}$ で ある. 被測定物の位置と曲率半径を最小 2 乘法で推定して除去

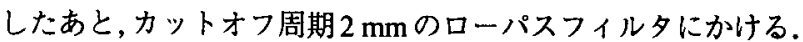
10 ラインのうち式 12 で計算する任意の 2 ラインの差 $E_{r}$ は 平均 $3.8 \mathrm{nmRMS}$ であり，評価値 $E_{s}$ は $2.4 \mathrm{nmRMS}$ であった。

また，最小 2 乗法で計算する被測定物の曲率半径は先端球の 大きさに影響を受けるはずである．先端球を交換しない場合，

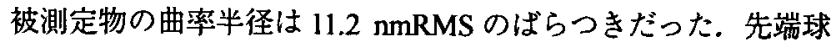
の交換を伴う場合は $14.4 \mathrm{nmRMS}$ となる。

\section{4-5 干涉計との比較}

総合的な測定精度を評価するため, さきほどの凹球面原器を 用い, 干涉計と比較した. ARuler は 5 回, 干涉計 (Zygo 社 Mk4： 精度 $1 / 10 \lambda$ )は 4 回の測定を行い，その平均形状を图 12 に示す. 測定再現性を平均形状からの差のばらつき $E_{s}$ で評価すると ARuler が 2.5 nmRMS，干涉計が 0.9 nmRMSであった.

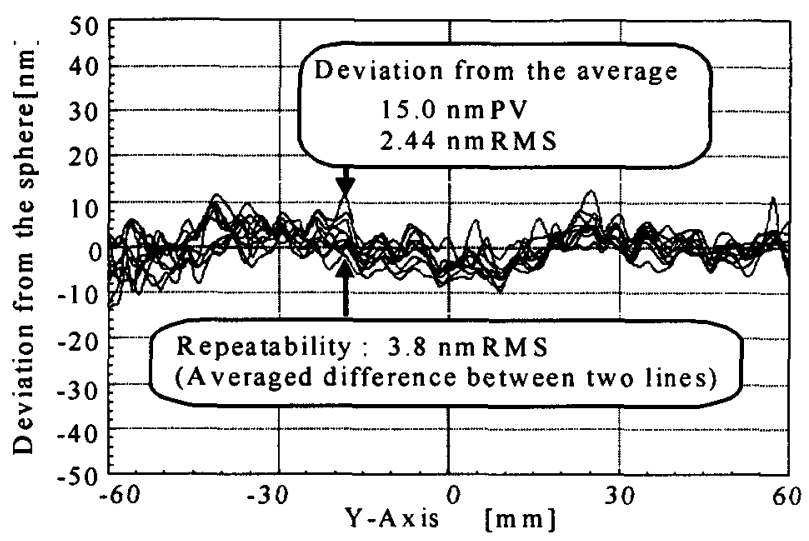

Fig. 11 Influence of tip-sphere's sphericity

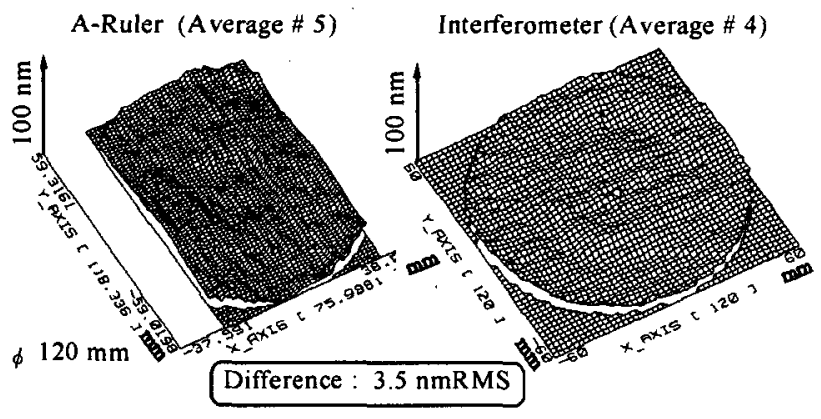

Fig.12 Cross check with an interferometer

そして平均形状の差をとると $3.5 \mathrm{nmRMS}$ となった. 前述した ように，全部の誤差要因が反映される球面の測定において干涉 計との差が目標に対して小さいことが確認できた。

\section{5 結論}

自由曲面を精度 $5 \mathrm{nmRMS}$ で測定する接触式の測定装置 ARuler 開発している.プロープの変形, 座標軸間直角度誤差 の影響を補償する方法を開発し，すべての誤差要因を含む球面 において装置性能を評価した。 $\oint 120 \mathrm{~mm}$, 最大傾斜角度 35 度に おいて繰り返し性 $3.8 \mathrm{nmRMS}$ が得られ, 干涉計と此較したとこ ろ両者の差は $3.5 \mathrm{nmRMS}$ であった。

今後, 形状誤差を有する球面を用いた場合の直角度誤差の補 償方法, および自由曲面における装置性能の評価が課題である.

\section{謝辞}

装置製作に同社，大石信司氏，出口明伸氏に尽力頂きました。

\section{参 考 文 献}

1) M. Negishi, M. Ando, M. Takimoto, A. Deguchi, H. Narumi, N. Nakamura and H. Yamamoto: A Super-Smooth Polishing for Aspherical Surface(I) -High-Precision Coordinate Measuring and Polishing Systems - , SPIE, 2576 (1995), 336.

2) M. Negishi, K. Watanabe, K. Matsushita, T. Kasahara and K. Hosaka: A High-Precision Coordinate Measurement Machine for Aspherical Optics, Proc. $9^{\text {th }}$-ICPE Japan, (1999) 354

3) M. Weiser, J. Froschke, H. Handschuh, M. Julich, M. Mayer and C. Seitz: Aspherical Surface at $100 \mathrm{pm}$ - Accuracy Results on Manufacturing and Metrology, Proc. $9^{\text {th }}$-ICPE Japan, (1999) 51.

4) K. Becker and E. Heynacher: A High Resolution Coordinate Measuring Machine for the Testing of X-Ray-Mirtor, SPIE, 733, (1986).149

5) P. B. Leadbeater, W. J. Wills-Moren and P. A. Mckeown: Ultra Precision Stylus Profilometry for Large Optical Components, ASPE, Annual Conf. , (1990) 114.

6) 吉住恵一，久保圭司:原子間カプロープ搭載超高精度三次元測定機, National Tech. Report, 39, 5 (1993) 598.

7) $\mathrm{H}$. Shiozawa and Y. Fukutomi: Development of an Ultra-Precision 3D-CMM with the Repeatability of Nanometer Order, Proc. $9^{\text {th }}$-ICPE (1999), 360. 